\title{
Pendampingan Civic Entrepeneurship di Era New Normal melalui Seminar Nasional
}

\author{
Meiwatizal Trihastuti \\ STKIP Pasundan, Cimahi \\ Corresponding Author: Meiwatiza197@gmail.com
}

\begin{abstract}
Info Artike
Diterima : 18/09/2021

Direvisi: 19/09/2021

Disetujui: $21 / 09 / 2021$

Abstract. The purpose of this activity is an effort made by a formal educational institution (STKIP Pasundan) as a step to prepare citizens with civic entrepreneurial competence. As one of the objects of a change in the paradigm of life in the new normal era, students are the main spear in creating a new mobility of life in accordance with the principles of civic entrepreneurship. This activity is carried out by conducting seminars through a planned procedure, namely the preparation stage by designing strategies and methods for delivering seminars. Then the implementation stage also ends with an in-depth evaluation and analysis in order to provide developments for further activities. The result of this activity is to have an impact on students' creativity and innovation by creating new opportunities in growing their competencies such as being independent, creative, brave, action-oriented, having a number of solutions and being able to create new opportunities.
\end{abstract}

Keywords: Mentoring, Civic entrerpreneurship, New normal era

Abstrak. Tujuan dari kegiatan ini merupakan usaha yang dilakukan oleh lembaga formal pendidikan (STKIP Pasundan) sebagai langkah untuk mempersiapkan warga negara dengan kompetensi civic entrerpreneurship. Sebagai salah satu objek adanya perubahan dalam paradigma kehidupan di era new normal mahasiswa merupakan tombak utama dalam menciptakan mobilitas kehidupan yang baru sesuai dengan prinsip civic entrerpreneurship. Kegiatan ini di lakukan dengan pelaksanaan seminar melalui prosedur terecana yaitu tahap persiapan dengan merancang strategi dan metode penyampain seminar. Kemudian tahap pelaksanaan juga diakhri dengan evaluasi dan analisis mendalam guna memberikan perkembangan untuk kegiatan selanjutnya. Hasil dari kegiatan ini ialah memberikan dampak pada kreatifitas dan inovasi mahasiswa dengan menciptakan peluang baru dalam menumbuhkan kompetensi dirinya seperti, mandiri, kreatif, berani, berorientasi pada tindakan, memiliki sejumlah solusi dan dapat menciptakan peluang baru.

Kata Kunci: Pendampingan, Civic entrerpreneurship, Era new normal

How to Cite: Trihastuti, M.(2021). Pendampingan Civic Entrepeneurship di Era New Normal melalui Seminar Nasional. Prima Abdika : Jurnal Pengabdian Masyarakat, 1(3), $107-113$. https://doi.org/10.37478/abdika.v1i3.1218

Copyright (c) 2021 Meiwatizal Trihastuti. This work is licensed under a Creative Commons Attribution-ShareAlike 4.0 International License.

\section{Pendahuluan}

Sebagai salah satu dampak dari perkembangan peradaban yang sangat cepat persebarannya tidak hanya berdampak kepada sektro industri tetapi juga berdampak kepada sektor pendidikan dan perekonomian. Entrerpreneurship menjadi isu yang sangat besar dan menarik untuk diperdebatkan dan diperbincangkan bukan hanya saja kaitannya dengan ranah ekonomi, tetapi juga dalam ranah kehidupan sosial, kesehatan, politik dan pemerintahan, bahkan pendidikan (Anwar, 2014).

Sebagai perbincangan dalam ranah pendidikan tentu saja hal ini akan melibatkan pendidik, peserta didik, proses pembelajaran dan hasilnya. Dengan kata lain bahwa entrerpreneurship dijadikan sebagai salah satu kompetensi yang harus dicapai dalam nilai kompetensi civic khususnya. Dalam rangakaian Enterpreneurship mempunyai nilai kebaikan seperti visi dan misi, kreatif dan inovatif, berani menanggung resiko, berjiwa kompetesi, mampu melihat dan menciptakan peluang, berjiwa social (Basrowi, 2011)

Robin dan Coulte dalam Tri \& Suyanto mengatakan bahwa entrerpreneurship merupakan proses dimana seorang individu maupun 
kelompok mencari peluang dengan upaya terorganisi dan sarana yang memadai untuk memenuhi keinginan dan kebutuhan melalui inovasi yang unik. Ahmad sanusia juga mengatakan bahwa Enterpreneurship Suatu nilai yang diterapkan dan diwujudkan dalam bentuk perilaku berupa sumber daya, tujuan, tenaga penggerak, kiat, proses, siasat dan hasil bisnis (Tri \& Suyanto, 2016). Setiap orang pada dasarnya memiliki jiwa entrerpreneurship tetapi dalam jumlah dan kadar yang berbeda. Dengan demikian aspek tersebut haruslah dieksplor dan diaplikasikan sehingga dapat berkembang menjadi suatu watak dan karakter yang baik (Kasmir, 2011)

Kemudian menurut Moko P. Astameon (2018) pada dasarnya bahwa jiwa entrerpreneurship ini tidaklah sekedar pengetahuan teknik saja, atau berupa keterampilan saja, tetapi lebih berorientasi pada sikap mental melalui proses diri dengan praktik dan pengalaman karena dorongan motivasi dirinya dan lingkungannya. Oleh karena itu pendidik sangat berperan untuk menciptakan stategi entrerpreneurship yang dapat menanamkan mental dan sikap yang kuat. Sehingga materi entrerpreneurship yang dikemas dan diajarkan melalui kegiatan pembelajaran tidak bersifat tekstual, tetapi bersifat kontekstual dan terapan yang dapat memberikan kesempatan kepada peserta didik dan mahasiswa khususnya untuk mengembangkan gagasan dan idenya.

Era New Normal merupakan pola kehidupan dengan kebiasaan baru yang mulai diterapkan dengan berdasarkan pada latar belakang adanya sebuah virus yang mendunia Covid 19. Dampak dari virus ini amat sangat dirasakan dalam semua sektor kehidupan khusunya pendidikan dan ekonomi, oleh karena itu, kedua hal ini merupakan salah satu bagian dari roda kehidupan yang ada di suatu negara dan dunia maka fungsinya tidak boleh dilumpuhkan (Anorga \& Sudantoko, 2020). Pola kehidupan new normal merupakan pola kebiasaan dengan pelaksanaan kegiatan sehari-hari dengan mengedepankan protokol kesehatan. Kebiasaan ini merupakan usaha yang dilakukan oleh pemerintah untuk mengembalikan fungsi sektor kehidupan yang sempat tidak berjalan. Oleh karena itu, seperti yang telah dikatakan oleh Rahmafitria et al. (2021) bahwa salah satu dampak positif dalam era ini ialah terbentuknya self efficiacy yaitu pengembalian fungsi sektor kehidupan merupakan langkah dalam menciptakan sikap seseorang. Menurutnya bahwa sikap seseorang sangat dipengaruhi oleh bagaimana persepsinya, maka untuk menghasilkan sikap yang positif maka perlu dibentuk konsepsi pengetahuan yang positif tentang pembentukan tanggung jawab seorang individu (Puspitaningsih, n.d.)

Selanjutnya Suryadi (2015) mengatakan bahwa adanya dampak penerapan era new normal juga membantuk seseorang untuk menyikapi persoalan kehidupan. Sehingga self efficiacy dan controllability dijadikan sebagai indikator dalam kontrol perilaku seseorang, maksudnya ialah melalui ini akan terbentuknya kesadaran positif yang memberikan dampak yang positif untuk dirinya dan lingkungannya. Sehingga pernyataan diatas semakain memperkuat analisis penulis bahwa dengan adanya pengabdian masyarakat melalui civic entrerpreneurship ini akan membantu terbentuknya paradigma baru. Hal ini juga disampaikan oleh Somantri (2012) bahwa untuk membentuk civic entrerpreneurship setiap individu haruslah siap untuk menerima dan melakukan mobilitas dan pembaharuan dalam pembentukan diri, sikap dan keterampilannya dan hal ini tentu saja tidak akan terlepas dari sentuhan teknologi. Melalui ha ini maka akan terbentuknya pola kehidupan, 
kebiasaan, pola pikir yang sesuai dengan tuntutan dan paradigma yang ada, sehingga civic Enterpreneurship berhasil dalam mencapai misinya menjadikan warga negara yang inovatif dan kreatif (Daryanto \& Karim, 2017)

\section{Metode Pelaksanaan}

Metode pelaksanaan pengabdian ini dilakukan dengan membagi dua tahap yaitu tahap persiapan dan tahap pelaksanaan seminar. Tahap persiapan merupakan kegiatan yang dilakukan oleh sebuah tim pengabdian sebelum kegiatan berlangsung, seperti dengan merancang startegi seminar, pembentukan panitia kegiatan hasil seminar.

Pada tahap pelaksanaan diserahkan kepada tim penyelenggara seminar. Dimana diawali dengan salam pembuka dan sambutan, kemudian penyampaian materi seminar oleh pemateri kegiatan ini dipandu oleh seorang moderator dan operator. Peserta seminar sendiri ialah Mahasiwa Prodi Pendidikan Pancasila dan kewarganegaraan STKIP Pasundan. Diakhir kegiatan seminar, moderator akan memberikan kesempatan kepada peserta seminar untuk melakukan tanya jawab.

\section{Hasil dan Pembahasan}

Kegiatan pengabdian civic Enterpreneurship ini dilakukan dengan rancangan strategi yang sudah melalui proses analisis dan survei terlebih dahulu oleh peneliti. Kegiatan ini dilakukan dengan berbasis digital dan online. Sesuai dengan urgensi penelitian bahwa hal ini perlu dilakukan agar tetap menumbuh kembangkan jiwa civic Enterpreneurship pada diri mahasiswa STKIP Pasundan.

Persiapan awal dilakukan dengan menggunakan dan menanamkan konsep pemahaman awal tentang civic dan entrerpreneurship yang dilengkapi dengan mengenai tatacara pelaksanaan seminar serta dokumen yang diperlukan dan yang akan digunakan dalam seminar. Pada tanggal pelaksanaan seminar dilaksanakan pada tanggal 18 September 2021. Adapun seminar tersebut terdiri dari 2 presenter dan 1 moderator, 2 orang operator, 1 orang notulen. Dan beberapa petinggi STKIP Pasundan yang memberikan sambutan pada pembukaan pelaksanaan seminar seperti tampak pada gambar 1 .

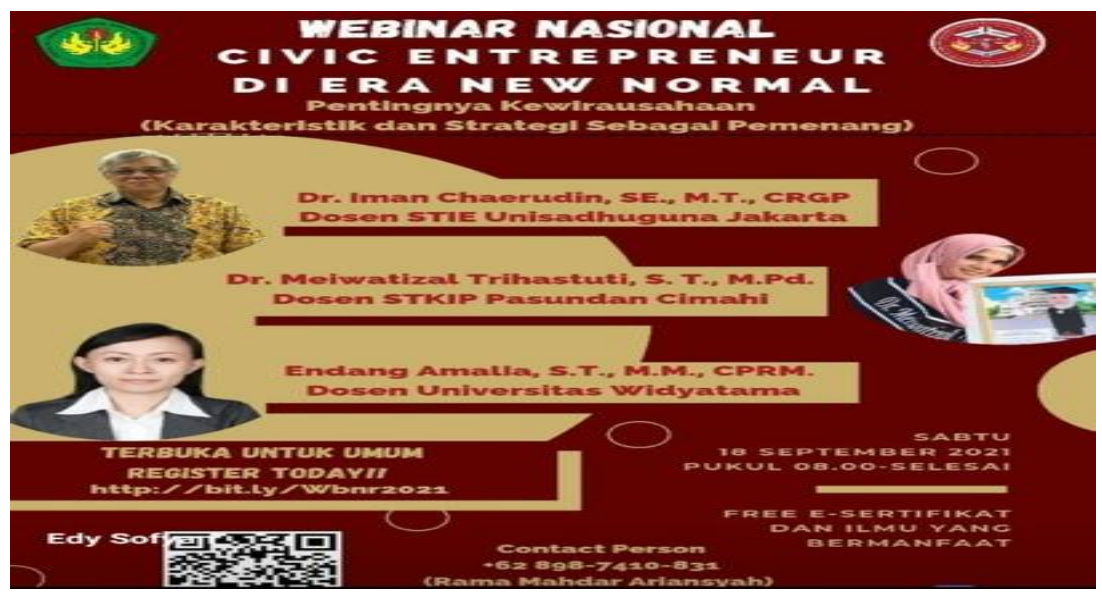

Gambar 1 Pelaksanaan seminar Civic Enterprenership di era new normal 
Setelah dibuka oleh moderatur, presenter pertama diberikan kesempatan untuk mempresentasikan, memberikan materi soal entrerpreneurship. Dalam proses tersebut presenter menyampaikan tujuan dilakukannya seminar dan penyampaian materi kedalam beberapa sub bagian yang dapat digambarkan, sbb :

Tabel 1. Materi seminar

\begin{tabular}{|l|l|}
\hline NO & \multicolumn{1}{|c|}{ Materi yang disampaikan } \\
\hline 1 & $\begin{array}{l}\text { Pengenalan biodata dan CV yang disampaikan oleh } \\
\text { moderator }\end{array}$ \\
\hline 2 & Penyampaian materi tentang Kewirausahaan \\
\hline 3 & Ciri dan karakteristik kewirausahaan \\
\hline 4 & Pengertian wirausaha Ciri wirausaha \\
\hline
\end{tabular}

Tidak hanya itu presenter pertama juga menyampaikan tentang bagaimana pertumbuhan dan Indeks Penjualan Ritel, 2019-2020. Penyampaian materi ini diberikan untuk memberikan motivasi kepada peserta seminar. Penyampaian materi seperti tampak pada gambar 2 berikut ini:

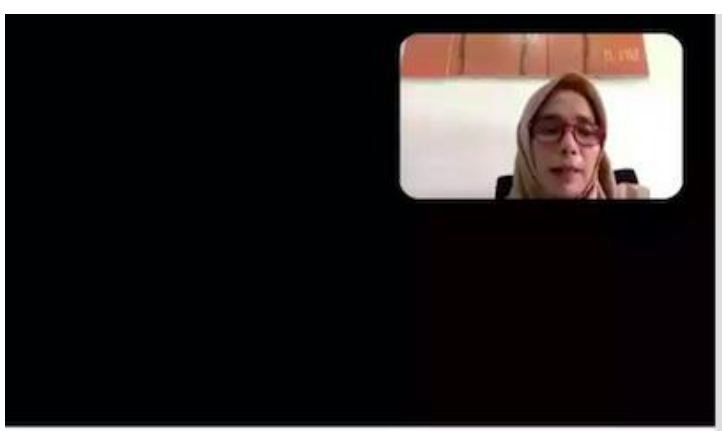

Civic Entrepreneurship di Era New Normal

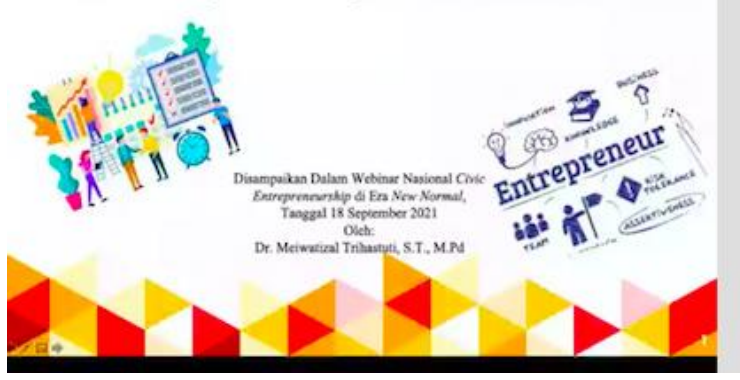

Gambar 2: Penyampain materi

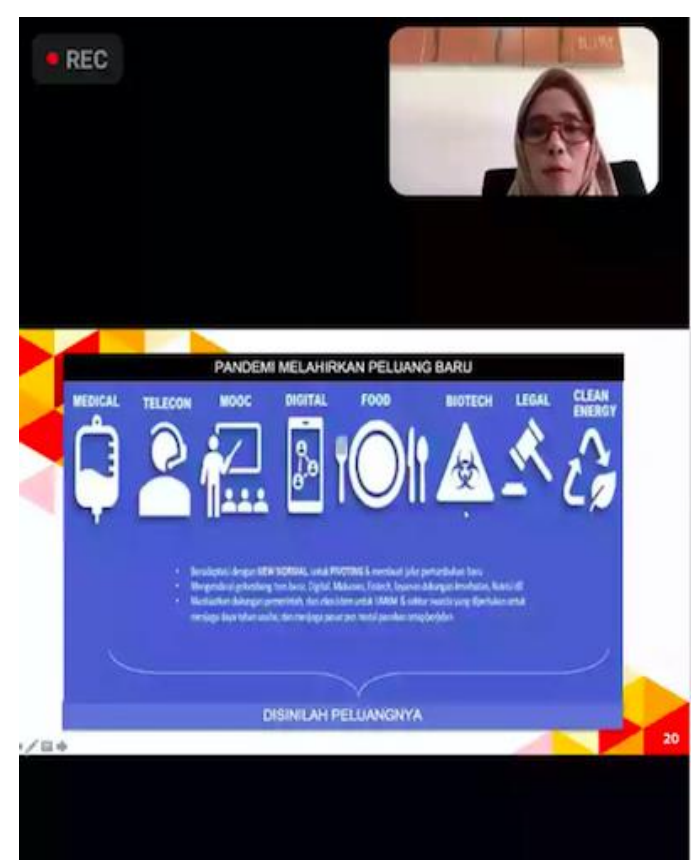

Tak hanya itu presenter juga memberikan dengan gambaran dan contoh yang sangat jelas beberapa tentang berbagai jenis bisnis statejik. Berikut dapat terlihat gamabaran yang telah disampaikan pada gambar 3 berikut ini 


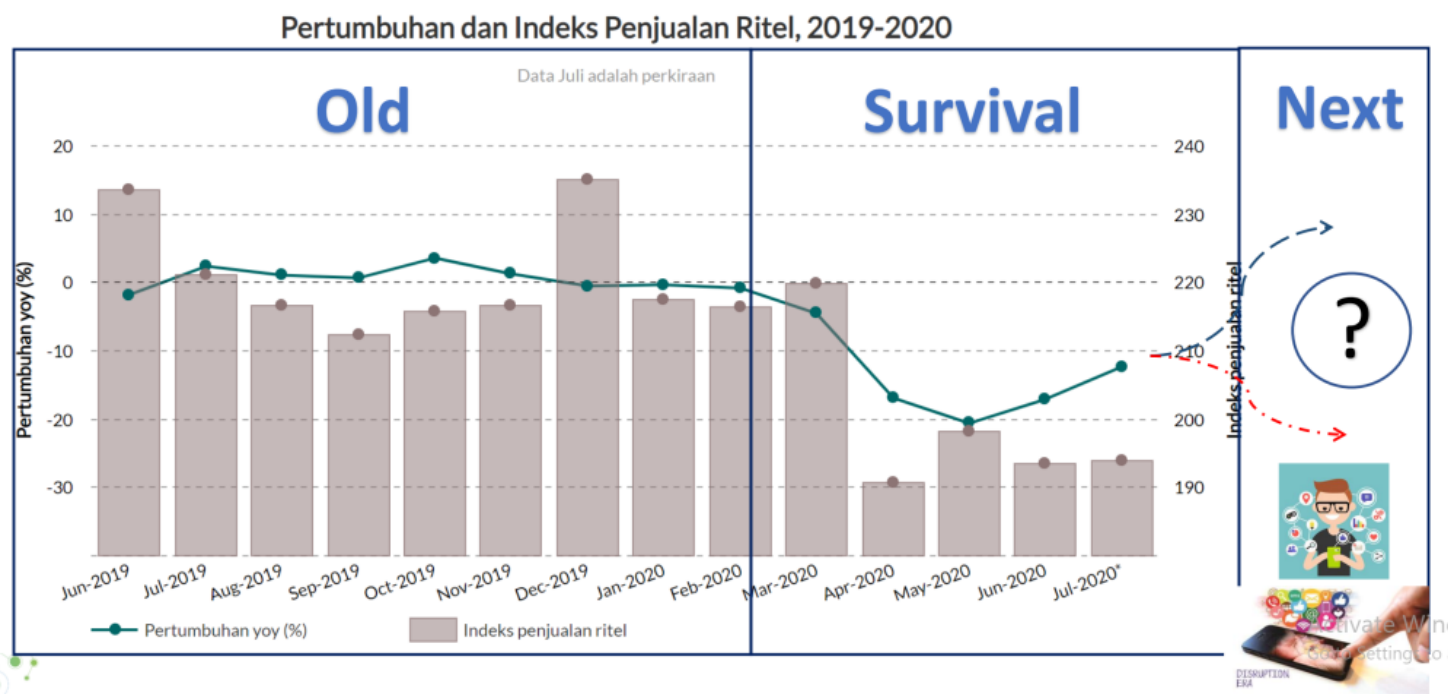

Gambar 3: Materi

Kemudian pada bagian presenter yang kedua. Presenter menyampaikan sesuai dengan fokus dan kajian pengabdian masyarakat yaitu tentang pendampingan civic Enterpreneurship. Pada bagian ini presenter lebih menitikberatkan kepada membangun jiwa generasi muda sebagai lambang dari peradaban dan adanya paradigma era new normal.

Pada pelaksanaanya, presenter tak hanya menyajikan materi, tetapi juga mampu menanamkan sikap dan mental entrerpreneurship dengan penjelassan materi yang dikaitkan dengan kondisi dan keadaan lingkungan yang akan terus berubah sesuai dengan tuntutan pembaharuan dunia. Maka sesuai dengan yang dikatakan oleh Louis Jacques Filion bahwa orang yang imajinatif, memiliki kemampuan menetapkan sasaran dan mencapai sasaran serta mempunyai kesadaran akan peluang yang ada, setelah itu membuat keputusan yang tepat.

Pada rancangan kurikulum dan tujuan pelaksanaan seminarnya presenter seminar telah merancang materi yang disampaikannya seperti yang tergambar 4 dibawah ini :
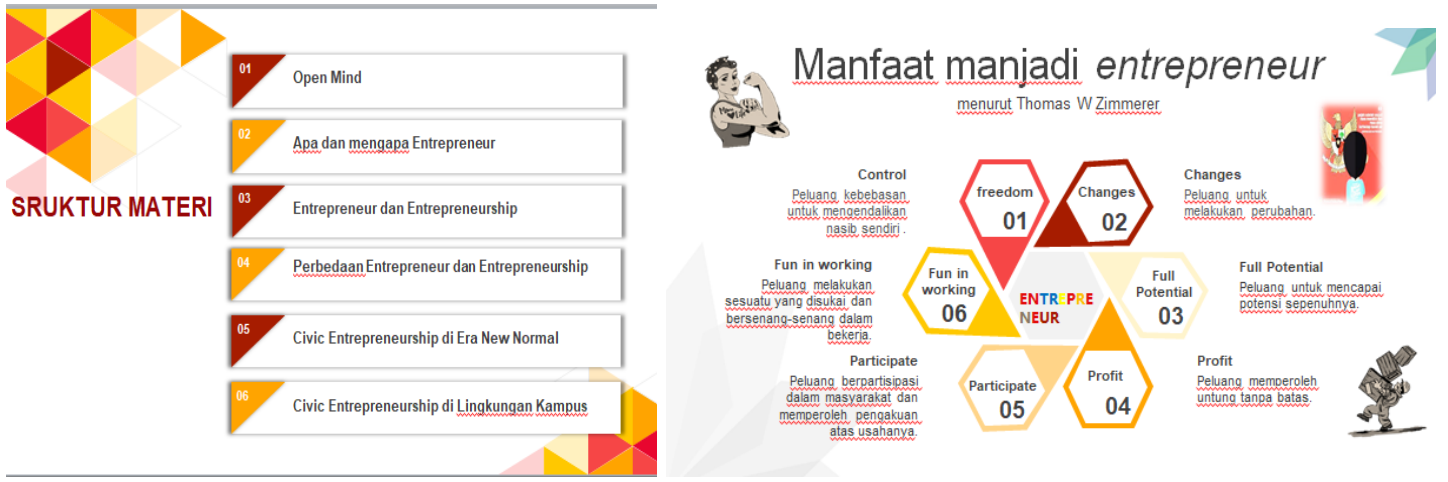

Gambar 4: Rancangan kurikulum dan tujuan pelaksanaan seminarnya presenter seminar telah merancang materi yang disampaikannya

Selanjutnya melalui kegiatan seminar tersebut, presenter juga menggunakan metode narasi dengan menceritaka beberapa tokoh atau kisah yang menginspirasi seperti kisah Mark Zuckerberg, Kisah Larry Page dan 
Sergey Brin, Kisah Achmad Zaky. Dengan harapan bahwa kisah ini akan membangun rasa tanggung jawab, percaya diri, berani dan juga inovatif. Seperti yang telah disampaikan oleh presenter pada kegiatan tersebut bahwa civic entrerpreneurship yang baik ialah Seseorang yang berani mengambil resiko dalam mengelola dan mengatur bisnis, wirausahawan tersebut nantinya akan memperoleh keuntungan finansial maupun non finansial.

Melalui penyampaian materi tentang civic entrerpreneurship presenter mengatakan bahwa ini merupakan usaha untuk menciptakan peluang dan usaha baru unruk bergerak, membuat kreatifitas dan inovatif dalam bentuk medical, digital, bahkan sampai dengan membantu seseorang secara mandiri beradaptasi dengan kegiatan dan pola kehidupan yang baru. Sehingga pada akhir penyampaian materi, melalui panduan moderator diberikan kesempatan kepada peserta seminar untuk melakukan diskusi dan tanya jawab secara terbuka tentang materi terkait yang disampaikan oleh presenter. Kegiatan diskusi sekaligus merupakan kegiatan evaluasi yang dilaksanakan oleh tim seminar STKIP dilingkungan kampus. Hal ini akan menjadi bagian dari bentuk analsis tim seminar pengabdian masyarakat.

\section{Simpulan dan Tindak Lanjut}

Tujuan dilakukannya kegiatan ini ialah utuk terciptanya budaya civic entrerpreneurship yang kreatif bagi mahasiswa dan lignkungan sekitarnya. Prosedur pelaksanaan seminar ini dilakukan dengan tahap perencanaan. Yaitu dengan melakukan tahap segala bentuk persiapan dan kebutuhan untuk kegiatan seminar tentang Pendampingan civic entrepenership di era new normal. Sedangkan tahap pelaksanaan dilakukan dengan berbasis online dengan pesertanya mahasiswa STKIP Pasundan.

Kegiatan ini diharapkan dapat menjadi sebuah awalan dan konsep baru untuk menciptakan sebuah inovasi seperti menciptakan Koperasi mahasiswa dan usaha lainnya yang dapat menampung kreatifitas tanpa batas yang dimiliki oleh mahasiswa. Nilai-nilai civic entrerpreneurship yang diamanatkan dalam kegiatan ini ialah nilai mandiri, kreatif, berani mengambil resiko, berorientasi pada tindakan, memiliki sejumlah solusi, dewasa dalam menghadapi suatu masalah, komitmen, kerja sama dan lain lain.

Sehingga kegiatan ini sesuai dengan tujuan pelaksanaannya dapat memperkuat nilai civic entrerpreneurship sebagai syarat kompetensi kewarganegaraan yang unggul dan kreatif. Yaitu warga negara yang siap dengan setiap perubahan dalam pelaksanaan kehidupan yang tetap memegang teguh prinsip wira ushaa yang berlandaskan pancasila dan kekeluargaan.

\section{Daftar Pustaka}

Anorga, P., \& Sudantoko, J. (2020). Koperasi: Kewirausahaan Dan Pengusaha Kecil. Rineka Cipta.

Anwar, M. (2014). Pengantar Kewiraushaan Teori dan Aplikasi. Ed 1. Prenadamedia Group.

Basrowi. (2011). Kewirausahaan untuk Perguruan Tinggi. Ghalia Indonesia.

Daryanto, \& Karim, S. (2017). Pembelajaran Abad 21 (Anggota IKAPI DIY (ed.); 1st ed.). Penerbit Gava Media.

Kasmir. (2011). Kewirausahaan. Rajawali Press. 
Moko P. Astameon. (2018). Entrepreneurship Dalam Perspektif Kondisi Bangsa Indonesia. Alfabeta.

Puspitaningsih, F. (n.d.). Pengaruh Efikasi Diri dan Pengetahuan Kewirausahaan Terhadap Minat Berwirausaha Melalui Motivasi. Tulunggaungng: STKIP PGRI,. Jurnal Ekonomi Dan Kewirausahaan.

Rahmafitria, F., Suryadi, K., \& Oktadiana, H. (2021). Applying knowledge, social concern and perceived risk in planned behavior theory for tourism in the Covid-19 pandemic. Tourism Review (Tourism Rev). https://doi.org/DOI:10.1108/TR-11-2020-0542

Somantri, N. (1976). Konsep Pendidikan Kewarganegaraan. Remadja Rosdakarya.

Suryadi, D. (2015). Penggunaan Pendekatan Tidak langsung Serta Pendekatan Gabungan Langsung Tidak langsung Dalam Rangka Meningkatkan Kemampuan Berpikir Matematik Tingkat Tinggi Siswa SLTP.

Tri, H., \& Suyanto. (2016). . Hubungan EQ, Pengetahuan kewirausahaan, dan hasrat marginal menabung, dengan motivasi berwirausaha mahasiswa Pendidikan Ekonomi. Jurnal Harmoni sosia. Jurnal Pendidikan IPS., Volume 3,(p-ISSN : 2655-7304 e-ISSN : 6655-8953), 95-104. 